\title{
The Impact of the Vocational Secondary Education in Kosovo's Economic Development in 2002-2017
}

\author{
Submitted 15/12/20, $1^{\text {st }}$ revision 20/01/21, $2^{\text {nd }}$ revision 25/02/21, accepted 20/03/21
}

\author{
Nexhit Shala ${ }^{1}$, Myrvete Badivuku-Pantina $^{2}$
}

\begin{abstract}
:
Purpose: This paper aims to research and determine the impact and role of vocational education in the country's economic development.

Design/Methodology/Approach: This paper was produced by combining descriptive statistical methods and econometric models, using primary and secondary data on vocational secondary education and economic development.

Findings: The results show that Vocational Secondary Education does not significantly impact economic development in Kosovo.

Practical Implications: With a well-organized and focused vocational qualification, economic sectors can be properly established and consolidated. This guarantees regular employment and economic development. Moreover, the lack of new jobs and the mismatch between VET and the labor market are some of the main challenges faced by Kosovan youth. Despite ongoing reforms in the education system and some economic indicators, Kosovo continues to face high levels of youth unemployment. In this regard, Kosovo's unemployment rate in 2019 was $25.70 \%$, while youth unemployment was even more highlighted, reaching the rate of $49.40 \%$. All of this leads to the conclusion that the Kosovo Government's priority should be the establishment and development of the country's education system, and as a result, this would affect the country's economic development.

Originality/Value: Findings from this study will be relevant to different ethnicities and not just individuals. Although the study will focus on Kosovo's example, its results could be used in other developing countries. The results will be important for policymakers and regulators, both in the economic field and in education and social development. Companies may be interested in supporting education in order to increase society's innovative capacity. Educational institutions would be recognized as important, and they could redirect their focus to highlighting the needs of the country's economy.
\end{abstract}

Keywords: Vocational education, economic development, Kosovo.

JEL codes: $M 14$, M15, M31.

Paper Type: Research study.

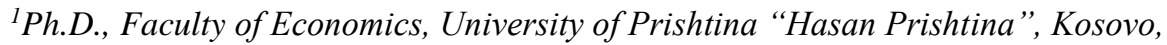
nexhit@gmail.com

${ }^{2}$ Lecturer, Faculty of Economics, University of Prishtina "Hasan Prishtina", Kosovo, myrvete.badivuku@uni-pr.edu
} 


\section{Introduction}

The progress of a country and the sustainable development of an economy is a fundamental matter globally, and these have expanded in the last two decades. The First Industrial Revolution began in the late 18th century. Since then, the concept of progress and prosperity has been linked to economic development. The economic competition of a nation has taken place depending on the capabilities of its workforce. On the other hand, the workforce's skills depend on the quality of education and vocational training provided in the country (Min, 1995). Vocational education and training are perceived as the essential elements in economic growth and development. Vocational education and training (VET) refer to the process of distributing and acquiring skills and abilities necessary for a vocation. These skills can be distributed at a general level and a tailored level to any individual or group. The vocational programs range can range from basic skill levels to specific fields such as fine and applied arts, agricultural sciences, home economics, automotive engineering, and computer science. Skills development programs are combined to provide knowledge to recipients and develop their future skills for sustainable development.

The concept of technological development and economic advancement revolves around a complementary and comprehensive vocational/ technical education program (Bulus, 1999: 22). Across the globe, contemporary education is costly. Therefore, any sound and sane mind do not foresee loss in education. The responsibility for ensuring a sound and strong vocational and technical education lies primarily within the laws and policymakers. It is the government's responsibility to maintain and distribute clean vocational programs/ skills. This skills development program is to be distributed using certain curricula and training programs, regardless of whether the nation's economy is in depression or not.

Past studies have shown that insufficient attention has been paid to the education sector, especially vocational skills. The main reasons for this involve poor policy implementation, teachers with poor educational power, inadequate vocational program design, and a general lack of governance mechanisms in vocational and educational training programs. Significant gaps in the implementation of vocational education/ skills development policies for our young people in the future could be reviewed by focusing them on vocational skills and mandatory vocational practicum. To emphasize this, the first and foremost step is to determine the extent of the impact of education and vocational training on the nation's economic development. Numbers can speak thousands of words. By the same token, efforts have been made to measure the impact of vocational education and training on Kosovo's economic development. This impact quantification will serve as an eyeopener for policymakers and industry groups to understand the importance of vocational education and training, and it is assumed that they would devise better plans to address this issue. 
Vocational Education and Training (VET) has become a tool for addressing social, political, and economic crises that continue to threaten the political and economic stability of some nations over a period of time. One of the reasons for the rise of this socio-political instability is the lack of meaningful jobs for young people. The rise of unemployment, high drop-out rates of formal education students, the lack of skilled workers in the industrial sectors, and changing demographic nature of the workforce are some of the reasons that have put the issue of higher education of the workforce on the educational reform agenda (Giroux, 1991).

Initially, when the concept of vocational education was introduced, the workforce was prepared for specific skills based on time needs. In the post-Taylorist work environment, attention was paid to the general skills that workers must possess when they are expected to perform more defined tasks (Hirsch and Wagner, 1995). This was the genesis of a broader education and training agenda on workforce skills development. In the new economic environment, vocational education is expected to produce an educated, skilled and motivated workforce (Mustapha, 1999).

In an international comparison, it was observed that employers in the US and the UK are not satisfied with the current establishment of VETs in their countries. They believe that the current state of VET programs and legislation around it are insufficient to effectively train the country's youth to change job requirements (Brown \& Keep, 1999). On the other hand, it is understood that employers in Australia are satisfied with their vocational education system (Fairweather, 1999).

This research on the perspective of vocational education in the economic development of industrialized countries has been extensively studied. Some of the prominent studies of the late 20th century are those of Bishop (1989), Carnevale and Schulz (1990); Lewis (1991); Clouse (1997); Mobley (1998); Williams and Hornsby (1989). The purpose of this study is mainly focused on Kosovo. This paper aims to research and determine the impact and role of vocational education in the country's economic development. Although the study was focused on data and information related to Kosovo, some of the study findings may apply to other countries with similar contexts.

\section{Methodology of Research and Hypothesis}

In the current research work, data have been downloaded from various sources such as the Kosovo Agency of Statistics (KAS), World Bank (WB), Employment Agency (EARK), the Ministry of Education, Science and Technology of Kosovo (MEST), Ministry of Labor and Social Welfare (MLSW) and other relevant resources. The time period for which data was collected varies from 2002 to 2017. Thus, the data set is a healthy data set of 15 years that should be sufficient to measure vocational training and achieve objectives. Since the data is downloaded from sources free of charge to everyone and all data is available in the public domain, there are no ethical or copyright issues related to the use of the data in the 
research work. The paper combines descriptive statistical methods and econometric models, using primary and secondary data on vocational secondary education and economic development.

The research that attempts to explore the challenges and opportunities of vocational education in the Republic of Kosovo is based on primary data collected from the field through questionnaires and personal interaction. From the first population, the statistical units were teachers and students. The sample was random nonprobabilistic, where 300 teachers from vocational schools in Kosovo were collected from teachers (the research was conducted online by sending questionnaires by email) and 500 students. Issues of interest were formulated in the research questions posed for this study. The elements, forms, and procedures of the survey instruments were based on existing research studies and literature on vocational education and training, educational reform, education economics, employment, schooling and business partnership, technical and technological preparation of students, the link between school and work, as well as current trends in education. The questionnaires were made the same for both samples. The questions in the questionnaire mainly raised closed questions with a Likert rating scale of 1 to 5 .

The questionnaire includes standard sections and the essential part in chapters (with approximately 30 questions). These four sub-sections of the questionnaire are Schooling Conditions, School Practicum, Communication with Students, Assessment, Methodology Used in the Classroom, Internship in Businesses, and Public Organizations.

The part of the research that explored and measured the impact of vocational secondary education on the Republic of Kosovo's economic development is based on secondary data and econometric models. The theoretical framework of the relationship between the dependent variable and the independent one is the basis of the whole study. An independent variable takes changing or distinguishing values during the study. The value of the dependent variable depends on the value of the independent variable. The relationship is a mathematical relationship. During the course of the study, an attempt was made to discover the reliable relationship between the dependent and independent variables.

The dual logarithm model is used for this case and has the form as follows:

$$
\log Y_{i t}=\beta_{0}+\beta_{1} \log X_{1}+\beta_{2} \log X_{2}+\beta_{3} \log X_{3}+D u m+\varepsilon
$$

where: $\log \mathrm{Y}_{\text {it }}$ - dependent variable (GDB as an indicator of economic growth); $\beta_{0}-$ is the constant term; $\beta_{j}$ - regression coefficient; $X$ - independent variable $\left(X_{1}\right.$ Governmental expenditures on vocational secondary education, $\mathrm{X}_{2}$-Number of students admitted in vocational secondary education as a percentage of the population, $\mathrm{X}_{3}$ - Employment);Dum -dummy variable; $\varepsilon$ - error term. 
To ensure that the results of the ordinary least squares (OLS) method are valid, random error normality tests, multicollinearity tests, and homoscedasticity tests were also carried out. SPSS and STATA were used as a software to carry out the data analysis. The raw data that has been downloaded has been put into several techniques to obtain meaningful information that supports the research objectives. Based on the research conducted, an empirical correlation has been established between vocational education and economic growth and regression analysis.

Several statistical and econometric techniques have been used to establish a correlation and an extension of one parameter's influence on another. The range of techniques has been disseminated during regression analysis, correlation analysis in root unit testing. These techniques try to explain one variable's movement with a change in the other/ set of variables. The result is quantified as a mathematical equation.

The first and foremost step was to carry out the root unit test on the time series data to check the data stationarity and integrate all variables. After determining the order of integration and setting time series stationed, regression analysis and hypothesis testing were carried out. Hypothesis testing determines the rejection or acceptance of an invalid hypothesis. Regression analysis was carried out to measure the impact and significance of each variable selected for the study. Finally, incremental causality was carried out with error correction to determine the causality direction between all variables.

\section{Hypothesis and Research Questions}

Based on the aims of the research, while working on this paper, the following research questions will be answered:

- Does secondary vocational education affect the promotion of economic growth?

- Is the vocational education that helps the individual get hired or selfemployed?

- Are inadequate infrastructure facilities affecting the development of vocational education?

- Is it the government that really helps vocational education teachers and students?

- Is it the lack of staff or teachers that affect the development of vocational education?

Hypothesis-based research was taken to accomplish the aims and objectives of the research. In hypothesis testing, the invalid hypothesis is assumed, and if the test results are irrelevant, the invalid hypothesis is rejected. In such a scenario, the alternative hypothesis is accepted. Based on the purpose of the paper and the above questions, the following study hypotheses will be developed and tested: 
H1: Vocational secondary education promotes economic development.

H2: Vocational secondary education promotes employment and self-employment.

H3: Infrastructure in vocational secondary education helps achieve the necessary skills for the labor market.

H4: Curricula and teachers are in function of achieving the necessary skills for the labor market.

H5: The government supports vocational secondary education.

\section{Summary of Results and Hypothesis Testing}

\subsection{Demographic Results}

The research was conducted online through the google form, the link distributed online on teachers' websites, and email addresses. A total of 300 teachers and 500 students participated in the research. There were 144 female and 156 male teachers, while 126 of them were from rural areas and 174 from urban areas. The average age was 37.5 years, while the average work experience was 13.91 years and the standard deviation was 7.40 years.

Regarding students, we could see that we have $32.8 \%$ female and $67.2 \%$ male students. Their participation from rural areas was $41.2 \%$ and from urban ones was $58.8 \%$. Excellent scores were $39.8 \%$, with a perfect score of $19.6 \%$, a sufficient score of $20.8 \%$, and a good score of $19.8 \%$, while approximately over $97 \%$ do not work during the summer season.

\subsection{Descriptive Results}

The first part of the questionnaire addressed questions about schooling conditions in school facilities, and the same questions were asked to teachers and students. The results show that in terms of school facilities for the development of theoretical and practical learning, we understand that there are facilities to some extent and that there is not much security for teachers, but the same situation applies to students.

Teachers and students agree that the lessons offered in schools allow those to be practiced in school through information technology, which is a very positive aspect, but that is not provided on every subject or subject area, and it is not possible for eve. ry student to practice or use technology, as confirmed by teachers and students.

The second part of the questionnaire deals with the forms of practicum in schools, where teachers and students generally have the same opinion. Regarding the possession of school laboratories, we have a bad situation in this aspect, and normally the possibility of practicum in the laboratory is impossible when those are lacking there, but if we look at the results it turns out that even when there are laboratories, the practicum is not carried out there. It is understandable that the classrooms do not posses information technology equipment such as projectors, 
computers or other technological devices, or have a very small percentage of them. They agree that lessons learned through practicum enable students to be more qualified, but this is not possible in most schools.

The third part of the questionnaire addresses the subject of communication between teachers and students. We see that in general we have a genuine communication between students and teachers despite the poor schooling conditions. Namely, we see that students are satisfied with their teachers in terms of teachers demands, but this level of satisfaction is not in terms of school practicum, while communication with them is commendable. A level of satisfaction has also been expressed by teachers, where they unanimously say that communication is good, but there is no opportunity for practicum in the classroom, in terms of practicing teaching units.

Assessment is considered as not being based on practicum, in most cases this assessment is based on theoretical work due to lack of facilities and laboratories, as well as the lack of information technology equipment in the classroom, especially on essential subjects. Even in the methodology used in teaching we see that we have setbacks, due to the fact that teachers say that they are not very satisfied with the application of various teaching forms, due to actual school conditions, while students prove that such a situation is the current one.

Regarding the internship in businesses and school institutions, the teachers say that is organized in a contracted arrangement, but they are not satisfied with the achievements and the manner of its implementation, while the students are very pessimistic in this aspect as they do not have the opportunity to apply the gained learning.

\subsection{Reliability Test}

The reliability test was conducted to verify the validity of our data, and they turned out to be at the level of acceptability; and we say that the average of the questionnaire data with teachers is .891, while among students, we have an average of .701. In this case, we could say that we can verify hypotheses through econometric tests.

\subsection{Test of Normality}

Test of normality was carried out to determine the normality of our data, which in our case have turned out to have abnormal or non-parametric distributions, and in this context, non-parametric econometric tests will be used to validate the hypotheses. Consequently, we can conclude that our data meet all the reliability conditions, which have been verified through Alpha Cronbach's test, and they turn out to have abnormal distributions or be non-parametric. In the following section, we will present econometric analyzes through questionnaires and secondary data. 


\subsection{CFA (Confirmative Factor Analysis)}

CFA (Confirmative Factor Analysis) was conducted for the teacher questionnaire to analyze the factor analysis. Based on the above results, we see that the data have a significant correlation in most cases,. Below is the table which sets out the standards to which our data should correspond.

Table 1. Fit Indices of Confirmative Factor Analysis

\begin{tabular}{|c|c|c|}
\hline Statistics & Perfect fit & Acceptable fit \\
\hline $\boldsymbol{\chi} 2 / \boldsymbol{d f}$ & $0 \leq \chi^{2 / d f \leq 2}$ & $2<\chi^{2 / d f \leq 5^{*}}$ \\
\hline $\boldsymbol{R M S E A}$ & $0 \leq R M S E A \leq .05$ & $.05<R M S E A \leq .08$ \\
\hline $\boldsymbol{T L I}$ & $95 \leq T L I \leq 1.00$ & $.90 \leq T L I \leq .95$ \\
\hline $\boldsymbol{C F I}$ & $.95 \leq C F I \leq 1.00$ & $.90 \leq C F I \leq .95$ \\
\hline$\chi 2$ Chi-Square; df=Degree of Freedom, RMSEA= Root Mean Square Error of \\
Approximation; TLI = Tucker Lewis Index; CFI=Comparative Fit Index, According to \\
$\begin{array}{l}\text { Schermelleh-Engel, K., Moosbrugger, H., \& Müller, H. (2003), *Marsh \& Hocevar, } \\
\text { (1985), **Hu \& Bentler (1998) }\end{array}$ \\
\hline
\end{tabular}

Source: Own creation.

Based on the analysis, the data obtained from the analysis through (Amos SPSS) are presented below and these confirm that the data are within the acceptable limits and can be continued with other analyzes.

Table 2. Organizational Justice Scale Adaptation Indexes

\begin{tabular}{|c|c|c|c|c|c|c|c|}
\hline & $\chi^{2}$ & $d f$ & $\chi^{2 / d f}$ & RMSEA & TLI & CFI & $\begin{array}{c}\text { Probability } \\
\text { Level }\end{array}$ \\
\hline Original model & 9307.104 & 390 & 23.864 & 0.00 & 1.00 & 1.00 & .000 \\
\hline
\end{tabular}

Source: Own creation.

Factor analysis - teacher questionnaire - is realized to determine the main factors that affect vocational secondary education, in certain topics. The results of the table below show that the test $\mathrm{KMO}=0.696$, Chi-square $=16.410 .206$, with a degree of freedom $\mathrm{df}=435$, while $\mathrm{p}$ value $=.000<1 \%$, therefore statistically we can proceed with the following analysis.

Table 3. KMO and Bartlett's Test

\begin{tabular}{|l|l|r|}
\hline Kaiser-Meyer-Olkin Measure of Sampling Adequacy. & 0.696 \\
\hline Bartlett's Test of Sphericity & Approx. Chi-Square & $16,410.206$ \\
\cline { 2 - 3 } & Df & 435 \\
\cline { 2 - 3 } & Sig. & 0.000 \\
\hline
\end{tabular}

Source: Own creation.

In the Total Variance Explained, we see that six components have managed to exceed the value of Eigenvalues over 1, the exact first component has reached the 
value of 14.301, second 4.207, third component has the value 3.183 , fourth 1.508 , fifth 1.239 , and the six component has the value 1.061 .

In the first components, the variables are classified with a high level of the coefficient. 'Assessment is based on the skills the students acquire' (.898), then 'I give students new information all the time (.853), 'The lessons I offer are consistent with the internships that students attend in businesses or public organizations' (. 842), and 'I communicate with students about the study units and provide information out of those offered by the books' (.835), which can be named as school conditions, while on the other hand with a high coefficient are the variables such as 'My demands are taken seriously by the students' (.785), 'Student assessment is based on theoretical and practical learning conditions' (.761), 'Students are close to teachers in terms of learning' (.731), 'Assessment is based on students' skills they acquire during theory' (.731), and 'The lessons offered by us, have the opportunity to be practiced through information technology as well (.707), that we can name as assessment and communication between students and teachers. In a word, the first component can be named the conditions of schooling, assessment, and communication.

In the second component are classified three variables, which are 'School has laboratories for each subject' (.881), 'Study units are practiced in the school laboratory, for the exact subject' (.861), and 'The practicum is offered for each subject' ( .827$)$, that we can designate as school practicum in laboratories.

The third component identifies three variables as the most important, such as 'Internships in businesses or public organizations they attend, enable them to achieve the skills required by the job market' (.879), 'Businesses or public organizations where students attend internships provide conditions and security for students and teachers' (.872), 'The skills that students acquire during internships in businesses or public organizations, enable them for their chosen vocation' (.846), and 'Internships are organized through contracted businesses or public organizations' (.808), which component can be named as student practicum in businesses and public organizations.

The fourth component has three variables, 'I use information technology tools or equipment during each lesson' (.840), 'School equipment is in the state-of-the-art and suitable for work' (.631), and 'Methodology used in schools creates the conditions for the development of innovations' (.607). This component can be named the use of information technology tools in the classroom.

In the fifth components are classified two variables as the 'The school provides sufficient space for the development of theoretical and practical learning' (.777) and 'Practical lessons in school enable students to be prepared for their internship in businesses' (.710), that means this component can be named as preparing students for the job market. 
In the sixth component, two components are distinguished as 'Assessment is based on students' abilities on the use of information technology equipment' (.336) and the 'School provides high security for students and teachers' (.444) can be named as student assessment.

\subsection{Hypothesis Testing}

H1. Vocational Secondary Education (expenditures on education, number of students in\% and employment in\%) promotes economic development.

Regression analysis was carried out to measure whether GDP is dependent on expenditures on education, the number of students in $\%$ and employment of citizens in $\%$. The analysis was carried out through linear regression, where the dependent variable is GDP, while the dependent variables are expenditures on education, number of students in $\%$, and employment in $\%$.

Table 4. Results of the regression analysis conducted through the SPSS programthe impact of vocational secondary education on promoting economic development

\begin{tabular}{|c|c|c|c|c|}
\hline \multirow{2}{*}{ Independent Variables } & \multicolumn{4}{|c|}{ Model -1- } \\
\cline { 2 - 5 } & $\mathrm{B}$ & S.H. & $\beta$ & Sig. \\
\hline Expenditures on education & 0.112 & 0.455 & 0.070 & 0.810 \\
\hline Number of students in\% & 0.099 & 1.149 & 0.024 & 0.933 \\
\hline Employment in\% & 0.150 & 0.105 & 0.409 & 0.177 \\
\hline $\mathbf{R}$ & \multicolumn{4}{|c|}{$0.440^{\mathrm{a}}$} \\
\hline $\mathbf{R}^{\mathbf{2}} 0.193$ \\
\hline$\Delta \mathbf{R}^{\mathbf{2}}$ & \multicolumn{4}{|c|}{0.007} \\
\hline $\mathbf{F}$ & \multicolumn{5}{|c|}{0.039} \\
\hline ANOVA (Sig.) & \multicolumn{5}{|c|}{ PBB } \\
\hline Dependent variable & \multicolumn{5}{|c}{} \\
\hline
\end{tabular}

Source: Own creation.

The above results indicate that in none of the cases was a significant impact found, precisely in the expenditures on education we have $(\mathrm{B}=.112, \mathrm{SH}=.455, \beta=.070$ dhe $\mathrm{p}$ value $=.810)$, then at number of students in $\%(\mathrm{~B}=.099, \mathrm{SH}=1.14, \beta=.024$ and $\mathrm{p}$ value $=.933)$ and at employment $\%(\mathrm{~B}=.150, \mathrm{SH}=.105, \beta=.409$ and $\mathrm{p}$ value $=.177$ ) that are over reliability level of $0.05 \%$.

So we say that GDP is not dependent on education expenditures, several students in $\%$ and employment in $\%$. To confirm more accurately, the OLS regression was presented, which was implemented through the STATA application.

Based on the analysis conducted through OLS regression, we understand and confirm the above analysis results that Vocational Secondary Education promotes economic development and has no significant impact on economic development in Kosovo. 
Table 5. Descriptive results of regression analysis - the impact of vocational secondary education on promoting economic development

\begin{tabular}{|c|c|c|c|}
\hline Source & SS & df & MS \\
\hline Model & .023963033 & 3 & .007987678 \\
\hline Residual & .004686967 & 14 & .000334783 \\
\hline Total & .02865 & 17 & .001685294 \\
\hline
\end{tabular}

Note: Number of obs $=17, F(3,14)=23.86$, Prob $>\quad F=0.0000$, R-squared $=$ 0.8364, Adj $R$-squared $=\mathbf{0 . 8 0 1 4}$, Root $M S=.0183$

Source: Own creation.

Table 6. Results of the regression analysis conducted through the STATA application - the impact of vocational secondary education on promoting economic development

\begin{tabular}{|c|c|c|c|c|c|c|}
\hline GDP & Coef. & Std. Err. & $\mathbf{t}$ & $\mathbf{P}>\mathbf{t}$ & {$[95 \%$ Conf. } & Interval] \\
\hline $\begin{array}{c}\text { EXPENDITURES } \\
\text { ON } \\
\text { EDUCATION }\end{array}$ & .101412 & .1331462 & 0.76 & 0.459 & -.1841582 & .3869823 \\
\hline Number & .7935124 & .8429509 & 0.94 & 0.362 & -1.014438 & 2.601462 \\
\hline Employment rate & .0367411 & .0885711 & 0.41 & 0.685 & -.1532251 & .2267073 \\
\hline
\end{tabular}

Note: On this occasion we say that statistically there is no significant impact of vocational secondary education on the economic development of Kosovo.

Source: Own creation.

H2: Vocational secondary education (school practicum, communication with students, assessment, methodology and internship in businesses) stimulates employment and self-employment.

Regression analysis was carried out to measure the dependence and impact of schooling conditions on school practicum, student communication, assessment, methodology used and internship in businesses.

Table 7. Regression results -the impact of vocational secondary education on the promotion of employment and self-employment

\begin{tabular}{|c|c|c|c|c|}
\hline \multirow[t]{2}{*}{ Independent Variables } & \multicolumn{4}{|c|}{ Model -1- } \\
\hline & B & S.H. & $\beta$ & Sig. \\
\hline School practicum & 0.758 & 0.022 & 0.860 & 0.000 \\
\hline Communication with students & 0.084 & 0.046 & 0.077 & 0.068 \\
\hline Assessment & 0.270 & 0.039 & 0.247 & 0.000 \\
\hline Methodology & -0.003 & 0.047 & -0.003 & 0.942 \\
\hline Internship in businesses & -0.208 & 0.023 & -0.245 & 0.000 \\
\hline $\mathbf{R}$ & \multicolumn{4}{|c|}{.939} \\
\hline $\mathbf{R}^{2}$ & \multicolumn{4}{|c|}{.882} \\
\hline$\Delta \mathbf{R}^{2}$ & \multicolumn{4}{|c|}{.880} \\
\hline $\mathbf{F}$ & \multicolumn{4}{|c|}{441.461} \\
\hline ANOVA (Sig.) & \multicolumn{4}{|c|}{.000} \\
\hline Dependent variable & \multicolumn{4}{|c|}{ Schooling conditions } \\
\hline
\end{tabular}

Source: Own creation. 
The above results indicate that coefficients have an impact in most cases, precisely at school practicums $(\mathrm{B}=.758, \mathrm{SH}=.022, \beta=.860$ and $\mathrm{p}$ value $=.000)$, then at assessment $(\mathrm{B}=.270, \mathrm{SH}=.039, \beta=.247$ and $\mathrm{p}$ value =.000 ) and internship in businesses $(\mathrm{B}=-.208, \mathrm{SH}=.023, \beta=-.245$ and $\mathrm{p}$ value $=.000)$ implying that these three factors depend on schooling conditions and this influence is statistically significant, $\mathrm{p}$ value $<0.1 \%$. In the other two cases, no significant correlation was found between student communication and research methodology.

The results show that vocational secondary education promotes employment and self-employment, but this has an impact only from school practicum, internship in businesses and forms of assessment, while in other cases it has no significant impact.

H3: The infrastructure in vocational secondary education is in function of achieving the necessary skills for the labor market

In order to measure whether the infrastructure in vocational secondary education is in function of achieving the necessary skills for the labor market, partial correlation was used where the correlation of schooling conditions and school practicum in relation to internship in businesses was measured.

Table 8. Correlation results - the impact of infrastructure in vocational secondary education on achieving the skills necessary for the labor market

\begin{tabular}{|c|c|c|c|c|}
\hline \multicolumn{5}{|l|}{ Correlations } \\
\hline \multicolumn{3}{|c|}{ Control Variables } & $\begin{array}{l}\text { Schooling } \\
\text { conditions }\end{array}$ & $\begin{array}{c}\text { School } \\
\text { practicum }\end{array}$ \\
\hline \multirow{6}{*}{$\begin{array}{l}\text { Skills for } \\
\text { labor market. }\end{array}$} & \multirow{3}{*}{$\begin{array}{l}\text { Schooling } \\
\text { conditions }\end{array}$} & Correlation & 1.000 & 0.897 \\
\hline & & $\begin{array}{l}\text { Significance (2- } \\
\text { tailed) }\end{array}$ & . & 0.000 \\
\hline & & df & 0 & 297 \\
\hline & \multirow{3}{*}{$\begin{array}{l}\text { School } \\
\text { internship }\end{array}$} & Correlation & 0.897 & 1.000 \\
\hline & & $\begin{array}{l}\text { Significance (2- } \\
\text { tailed) }\end{array}$ & 0.000 & . \\
\hline & & $\mathrm{df}$ & 297 & 0 \\
\hline
\end{tabular}

Note: Based on the above results we see that we have a high positive correlation $(r=.897$ **, $p$ value $=.000)$ which is significant at $0.01 \%$ of the confidence level. In this case we say that statistically the school conditions and school practices which directly coincide with the infrastructure in education, have a positive impact on the achievement of skills in the workplace.

Source: Own creation.

H4: Curricula and teachers are in function of achieving the necessary skills for the labor market

To analyze whether the curricula and teachers are in function of achieving the skills needed for the labor market, I used the Spearman correlation, while the independent variable is the curriculum, the dependent variable are the skills for the labor market. 
Table 9. Correlation results - linking curricula and teachers in order to achieve the necessary skills for the labor market

\begin{tabular}{|l|l|l|r|r|}
\hline \multicolumn{3}{|l|}{ Correlations } & $\begin{array}{c}\text { Curricul } \\
\text { a }\end{array}$ & $\begin{array}{c}\text { Skills for labor } \\
\text { market }\end{array}$ \\
\hline \multirow{3}{*}{$\begin{array}{l}\text { Spearma } \\
\text { n's rho }\end{array}$} & Curricula & $\begin{array}{l}\text { Correlation } \\
\text { Coefficient }\end{array}$ & 1.000 & $0.446^{* *}$ \\
\cline { 3 - 5 } & Sig. (2-tailed) & & 0.000 \\
\cline { 3 - 5 } & $\mathrm{N}$ & & 300 \\
\cline { 3 - 5 } & $\begin{array}{l}\text { Internship in } \\
\text { businesses }\end{array}$ & $\begin{array}{l}\text { Correlation } \\
\text { Coefficient }\end{array}$ & & \\
\cline { 3 - 5 } & Sig. (2-tailed) & & \\
\cline { 3 - 5 } & $\mathrm{N}$ & & \\
\hline
\end{tabular}

Note: The above results show that we have a positive correlation (rho $=.446 * *, p$ value $=$ .000) which means that curricula and teachers are a factor in raising awareness of achieving skills for the labor market, $p$ value $<0.01 \%$.

Source: Own creation.

H5: The government supports vocational secondary education.

To verify whether the government supports vocational secondary education, I used the Spearman correlation, where the independent variable is GDP, while the dependent variable is the number of students in $\%$ and employment in $\%$. An element of this issue was also confirmed through regression, but here we want to see if we have significant relations.

Table 10. Correlation results - whether the government supports the vocational secondary education

\begin{tabular}{|c|c|c|c|c|c|}
\hline \multicolumn{6}{|l|}{ Correlations } \\
\hline & & & PBB & $\begin{array}{c}\text { Number of } \\
\text { students in } \%\end{array}$ & $\begin{array}{l}\text { Employment } \\
\text { in \% }\end{array}$ \\
\hline \multirow[t]{9}{*}{$\begin{array}{l}\text { Spearman's } \\
\text { rho }\end{array}$} & \multirow[t]{3}{*}{ PBB } & $\begin{array}{l}\text { Correlation } \\
\text { Coefficient }\end{array}$ & 1.000 & 0.042 & 0.479 \\
\hline & & Sig. (2-tailed) & & 0.874 & 0.052 \\
\hline & & $\mathrm{N}$ & 17 & 17 & 17 \\
\hline & \multirow[t]{3}{*}{$\begin{array}{l}\text { Number of } \\
\text { students in \% }\end{array}$} & $\begin{array}{l}\text { Correlation } \\
\text { Coefficient }\end{array}$ & 0.042 & 1.000 & 0.270 \\
\hline & & Sig. (2-tailed) & 0.874 & & 0.295 \\
\hline & & $\mathrm{N}$ & 17 & 17 & 17 \\
\hline & \multirow[t]{3}{*}{$\begin{array}{l}\text { Employment in } \\
\%\end{array}$} & $\begin{array}{l}\text { Correlation } \\
\text { Coefficient }\end{array}$ & 0.479 & 0.270 & 1.000 \\
\hline & & Sig. (2-tailed) & 0.052 & 0.295 & \\
\hline & & $\mathrm{N}$ & 17 & 17 & 17 \\
\hline
\end{tabular}

Note: Based on the above results we see that between GDP and Number of students in\% we have $($ rho $=.042, p$ value $=.874)$, while GDP and Employment in \% we have (rho $=.479, p$ value.052) that implies that in neither of cases, there is no significant positive relation.

Therefore, we can say that the government does not support vocational secondary education.

Source: Own creation. 


\section{Conclusion}

Vocational education and training are perceived as the essential elements in the country's economic growth and development. VET is among the most important components of human capital. The depth of technological education and training in a society is related to its mass education system. It is a direct relationship that shows that economic development cannot be achieved without technical and professional competence. Every country must develop a VET system for its youth to have a competitive advantage in the market and match the labor demand demands.

Across the globe, contemporary education is costly. Therefore, any sound and sane mind do not foresee loss in education. The responsibility for ensuring a sound and strong professional and technical education lies primarily within the country's laws and policymakers. It is the government's responsibility to maintain and distribute clean vocational programs/ skills. This skills development program is distributed using certain curricula and training programs regardless of whether the nation's economy is in depression or not:

- The results show that Vocational Secondary Education does not have a significant impact on economic development in Kosovo; therefore, we say that GDP is not dependent on expenditures on education, number of students in $\%$ and employment in\%;

- The results show that vocational secondary education promotes employment and self-employment, but this has an impact only from school practicum, an internship in businesses and forms of assessment, while in other cases it has no significant impact;

- The results show that statistically, school conditions and school practicums which directly coincide with the infrastructure in education, have a positive impact on the achievement of skills in the workplace;

- The results show that curricula and teachers are factors that influence the raising of awareness about achieving skills for the labor market;

- The results show that the government does not support vocational secondary education.

Kosovo's workforce is mainly young, which was carefully assessed as an important potential for human capital development. However, vocational qualification at various levels of the economy is almost completely lacking. With a well-organized and focused vocational qualification, economic sectors can be properly established and consolidated. This guarantees regular employment and economic development. However, from an internal perspective, this presents an increased burden on the education system (vocational education and training) and Kosovo's labor market. Also, the lack of new jobs and the mismatch between education and the labor market are some of the main challenges facing Kosovar youth. Despite ongoing reforms in the education system and some economic indicators, Kosovo continues 
to face high levels of youth unemployment. All of this leads to the conclusion that the Kosovo Government's priority should be the establishment and development of the country's education system, and as a result, this would affect the country's economic development.

\section{Recommendations}

\subsection{The Relationship Between Vocational Education and the Labor Market}

The system must constantly adapt to the changing needs of the labor market and society. The relationship between vocational education and the labor market remains a challenge that requires immediate treatment because vocational school curricula offer profiles that are not in high demand in the market. This also contributes to raising the wider profile of VET in society, which has a positive effect on responding to VET programs as they receive more attention from a wider group of potential applicants. To achieve this goal, the following actions must be taken:

- A detailed research of the relationship between vocational education and the labor market, by the competent ministries, municipal directorates, vocational secondary schools, and businesses;

- Upon the research results, to reorganize VET profiles;

- Admission of students to be carried out only for those profiles for which the market lacks labor force;

- Municipal directorates to reach agreements with businesses, enabling the conditioning that internship has to be ensured in advance and then admission in VET to take place.

- Replacement or training of VET teachers to ensure that they are updated with the latest VET knowledge.

\subsection{Capacity Building in All Areas of the Economy}

The need for qualified workers has increased in recent years and may increase even more shortly. Poor skills between the workforce and inadequate vocational education are some of Kosovo's main problems in terms of the labor market. To achieve this goal, Kosovo should take as a model one of the education systems implemented in Germany, Switzerland, or Austria.

A key factor in Germany's success has always been people's qualifications in all areas of the economy. Quality products and effective services can be provided only if employees perform their work with the highest quality level. To this end, a qualification system has been set up in Germany, maintained and improved by all economics, politics, and education actors. The essence of this qualification is the dual principle. At all levels of qualification, theory and practice are linked so that 
young people are prepared to provide quality work today and build new approaches tomorrow, together with policymakers.

This form of vocational education has long been successfully developed in both Austria and Switzerland. Kosovo should follow this many years of experience. To achieve this goal, the following actions should be taken:

- Government should develop policies to encourage companies to engage in dual education programs;

- Cooperation with businesses - Competent institutions have not managed to promote the participation of businesses in VET. Business cooperation with providers of vocational education and training for quality skills and attractive future. The main reason for such cooperation is that VET will be in line with the needs of (future) students and employers. Work-based learning is essential to maximize the skill matching process. Thus, matching skills and work-based learning reinforce each other, and both contribute towards increasing the quality and attractiveness of VET;

- Increasing the value of VETs - a more structured approach is needed to raise awareness of the importance of vocational education and employment opportunities that this sector brings to the younger generations. To increase the value of VET, the Government should establish a model to promote VET;

- The government should develop policies to encourage companies to invest in the private sector as well;

- The government should develop policies so that VET programs are valid not only at the national level but also at the international level;

- The government should develop policies for continuing vocational education;

- The government should develop policies ensuring that the standards of the vocation by the European Qualifications Framework are being implemented, and verify that the person who has completed a VET is competent to perform the job;

- Labor legislation should prioritize persons who have completed VET about persons who have not completed VET.

\subsection{Increasing Investments in VET}

The budget dedicated to vocational education and training should be significantly increased in order for this area to be a priority. Vocational schools have many difficulties in terms of practicum and internships, working conditions and equipment needed for laboratories and workplaces, and qualified staff who can provide knowledge to program participants. Therefore, a key step in this subject is a larger budget allocation for vocational schools. Expenditures on vocational education and training will have direct effects on: 
- Infrastructure in vocational secondary education to be in function of achieving the necessary skills for the labor market;

- Curricula and teachers to be in function of achieving the necessary skills for the labor market;

- School practicum, communication with students, assessment, methodology and internship in businesses to promote employment and self-employment.

\section{References:}

Agjencia për Arsim dhe Aftësim Profesional dhe Arsimin e të Rriturve (AAAPARr). Agjencia për Regjistrimin e Biznese në Kosovë (ARBK), Regjistri i Bizneseve 2016.

Bishop, J. 1989. Occupation training in high schools: When does it pay off? Economics of Education Review, 8(1), 1-15.

Brown, A., Keep, E. 1999. A UK perspective on how well initial vocational education and training facilitates lifelong learning. Paper presented at the European Conference on Educational Research, Lahti, Finland.

Bulus, F. 1991. Guidance practice in Schools. Jos: Ehindero (Nigeria) Ltd.

Carnevale, B., Schulz, E. 1990. Technical training in America: How much and who? Training and Development Journal, 42(11), 18-32.

Clouse, J.R. 1997. A study of employer satisfaction of vocationally trained students by Saline County Career Center. Unpublished educational specialist thesis, Central Missouri State University.

Fairweather, P. 1999. Employers' perceptions of training and the way forward. In: Robinson, C., Arthy, K. (Eds.), Lifelong learning: Developing a training culture. Leabrook, South Australia: NCVER.

Giroux, H. 1991. Series introduction: Reading work education as the practice theory. In: R.I.Simon, Dippo, D., Schenke, A. (Eds.), Learning work: A critical pedagogy of work education. New York: Bergin \& Garvey.

Gjoshi, R. 2016. Mësimdhënia E Gjuhës Shqipe Në Kosoove (aspekte historike dhe didaktike). Monografi, Armagedoni, 394.

Hirsch, D., Wagner, D.A. 1995. What makes workers learn: The role of incentives in workplace education and training. Cresskill, NJ: Hampton Press.

Kosova, Vështrim Monografik, Akademia e Shkencave dhe e Arteve e Kosovës, Prishtinë, 2011.

Lewis, T. 1991. The global economy and education for work in the United States. Journal of Vocational Education Research, 16(2), 1-32.

Limani, M. 2002. Hyrje ne Ekonomi, Kolegji Biznesi, Fakulteti Ekonomik.

Limani, M. 2008. Ekonomia E Kosoves Neper Peridha Historike, Kolegji Biznesi, Fakulteti Ekonomik.

Min, W. 1995. Vocational education and productivity. In M. Carnoy (Eds.), International encyclopaedia of economics of education, 140-145. Oxford: Pergamon.

Ministria e Arsimit, Shkencës dhe Teknologjisë. Shënime Statistikore 2016-17 Arsimi Parauniversitar.

Mobley, C.D. 1998. North Carolina employers' perceptions of essential skills for entry-level employment of high schools graduates: Implications for educational leadership. Unpublished doctoral dissertation, East Carolina University. 
Mustapha, R. 1999. The role of vocational and technical education in the industrialization of Malaysia as perceived by educators and employers. Unpublished doctoral dissertation, Purdue University, West Lafayette, IN.

Williams, C.G., Hornsby, H.H. 1989. Vocationalism in U.S. and U.K. high schools. Economics of Education Review, 8(1), 37-47.

Zogaj, A., Abdixhiku, L., Mustafa, M., Hashani, A., Gashi, P., Mustafa, P., Havolli, S., Rizvanolli, A., Toçi, V., Krasniqi, B., Demukaj, Reçica, F. 2018. Ekonomia e Kosoves, Riinvest. 